Trinity University

Digital Commons@ Trinity

Economics Faculty Research

Economics Department

Spring 2003

\title{
In Medio Stat Virtus: An Alternative View of Usury in Adam Smith's Thinking
}

Maria Pia Paganelli

TrinityUniversity, mpaganel@trinity.edu

Follow this and additional works at: https://digitalcommons.trinity.edu/econ_faculty

Part of the Economics Commons

\section{Repository Citation}

Paganelli, M.P. (2003). In medio stat virtus: An alternative view of usury in Adam Smith's thinking. History of Political Economy, 35(1), 21-48. doi: 10.1215/00182702-35-1-21

This Article is brought to you for free and open access by the Economics Department at Digital Commons @ Trinity. It has been accepted for inclusion in Economics Faculty Research by an authorized administrator of Digital Commons @ Trinity. For more information, please contact jcostanz@trinity.edu. 


\title{
In Medio Stat Virtus: An Alternative View of Usury in Adam Smith's Thinking
}

\author{
Maria Pia Paganelli
}

Some specific positions of Adam Smith have been, and still are, sources of problems and debates. Generally, the controversies concern apparent contradictions in the Smithian theory. An example of these puzzling contradictions in Smith is his position on usury laws:

In countries where interest is permitted, the law, in order to prevent the extortion of usury, generally fixes the highest rate which can be taken without incurring a penalty. This rate ought always to be somewhat above the lowest market price, or the price which is commonly paid for the use of money by those who can give the most undoubted security. (WN, II.iv.14)

How could a believer in the beauty and power of the market favor usury laws?

Modern literature tries to answer this question in at least three fashions: a "nonsense" interpretation, a "Keynes-like" interpretation, and a "Stiglitz and Weiss-like" interpretation. I will argue that these interpretations of Smith on usury laws are unsatisfactory because they neglect

Correspondence may be addressed to Maria Pia Paganelli, Department of Economics, Yeshiva University, 500 W. 185th Street, New York, NY 10033; e-mail: paganell@ymail.yu.edu. I thank Tyler Cowen for his inestimable help, advice, and support. I am grateful for the inspiration and encouragement received from David Levy, and for the comments of two anonymous referees. The remaining mistakes are mine. In this article, references to The Wealth of Nations are given as "WN," followed by the book, chapter, section (when applicable), and paragraph numbers; references to The Theory of Moral Sentiments are given by "TMS," followed by the part, section, chapter, and paragraph numbers.

History of Political Economy 35:1 @ 2003 by Duke University Press. 
Smith's contextual knowledge. ${ }^{1}$ I will show how the key to understanding the consistency of Smith's position on usury can be found in the difference between his contextual knowledge and ours. ${ }^{2}$

Unlike most modern economists, Smith is a moral philosopher. Smith has a well-developed classical and, I would argue, consistent view of the world. In general, for the classical Greeks and Romans, extremes are dangerous because they are too far away to be seen and known. A middle position is therefore preferred to an "extreme" position. Moreover, differently from modern economics, which assumes that information is unbiased and behavior is error-free, ${ }^{3}$ Smith's economics observes and analyzes systematic biased information that leads to systematic errors. By acknowledging systematic bias and preferring a middle position, it is possible to make sense of Smith's position on usury.

Evidence that understanding Smith's defense of usury laws requires the tools of moral philosophy and systematic biases can be found in the extensive use of these two instruments in The Wealth of Nations and The Theory of Moral Sentiments, as well as in the interaction between Smith and his most famous intellectual adversary on usury-Jeremy Bentham.

To show how usury laws make sense in Smith's world, but not in Smith's world seen through some modern lenses, I will consider the possibility of reaching Smith both "from the past" and "from the future." Reaching Smith's position on usury laws from the past is my present attempt. Trying to reach Smith from the future is what current literature on Smith and usury laws has unsuccessfully tried.

\section{Reaching Smith's Position on Usury with the Instruments Available in His Day}

Before being the father of economics, Adam Smith was a professor of moral philosophy. I will therefore look into the "toolbox" of moral philosophy to find interpretative instruments.

1. On the difference between a modern-looking "rational reconstruction" and a historical analysis more respectful of the original context of an author ("historical reconstruction"), see Blaug 2001. For recent works on Smith that take into account his historical and intellectual context, see Tribe 1999, Evensky 1998, Evensky 2001, and Young 1997.

2. My interest is strictly to analyze Smith's consistency as a thinker, regardless of whether his theories are correct or not.

3. A major attempt to recognize the existence of bias and incorporating biased behavior in economic analysis can be found in Kahneman and Tversky 1979 and in Kahneman, Slovic, and Tversky 1982. 
Smith lived during the transition from the ancien régime to modernity. The principles (economic and otherwise) to which Smith subscribed coincide with some principles that are still recognized today, but Smith's understanding of economics was informed by his knowledge of Greek and Roman literature (see Paganelli 2000 and Griswold 1999). So, while Smith rejects a theological justification of usury laws, which was proposed by many before him, ${ }^{4}$ he also does not embrace a more amoral rationality, which some of his contemporaries of less classical education more likely held.5 As I will show below, Smith's justification of usury laws was nonreligious (in contrast with most of his predecessors) but rested on a moral base (in contrast with most of his contemporaries and successors).

\section{The Classical Medietas}

In the eighteenth century, moral philosophy was still heavily based on the works of the ancient Greeks and Romans. Smith gives us evidence in all his works of his deep knowledge of the classics.

The Greeks taught Smith that the good, the virtuous, lies within bounded limits. The Greeks, for instance, lived in a bounded polis. They expanded by poleis only, creating brand new poleis rather than developing around existing ones. Outside the limits of the polis, Aristotle reminds us, there are only gods or beasts, because what is not bounded is not human. Infinity, indeed, is nonhuman, dangerous, and paradoxical. Infinity is not good for humans, because it is not bounded, and therefore not knowable. 6 What is knowable is only what can be measured, and what can be measured has to be bounded. As a consequence, the "sin" of hubris was the most nefarious and infamous act a person could commit. Hubris meant challenging the gods; it meant going outside the limits. The sailors who tried to cross the pillars of Hercules, which were the borders of the world, died throwing up green bile. What did all this mean? It meant that extremes were dangerous, that extremes were to be

4. For an overview of the religious justification of usury laws, see Nelson 1969.

5. See, for example, Jeremy Bentham's "Defence of Usury" ([1787] 1952).

6. See, for example, Plato's considerations of the lack of order associated with infinity in Philebus (24a-26d), Aristotle's analysis of the many problems deriving from the idea of infinity in Physics (III, 5, 204a and following), or the more popular paradox of Zeno's tortoise, in which a slow-moving tortoise wins a race against the swift-footed Achilles. 
avoided. It meant that being in the "middle" was the good thing to do. Greek ethics is a reflection of this.

The Greeks were not unique. The Romans developed a similar ethical system: avoid the extremes and stay in the middle. Virtue is the middle point between two extremes. It is the balance between opposites. It is moderation. Choosing to moderate all passions leads one to the "just middle." In other words, the way to moral excellence is medietas or mediocritas (being in the middle). ${ }^{7}$ It follows that the virtuous man is the prudent man, the man who has reached an internal balance within himself, who has his "soul in its just and proper order." And the social nature of human beings implied that the virtuous behavior of the individual is possible thanks to conscious choice and his interrelations with the other individuals in the orderly society.

This concept of medietas (in modern statistical terminology, the median) was the pivot around which revolved not just the classical world but also the medieval world and the world of the ancien régime. ${ }^{8}$ Not by chance, Cicero's De Officiis was a major textbook until the nineteenth century. And during the ancien régime, as well as during the classical age, individual virtue and social virtue were strictly related. Virtuous individuals would create a virtuous society, and a society with virtuous moral rules would give individuals incentives to become virtuous. This interdependence between the medietas of the individual and of the virtues of the society in which he lived is exemplified, among others, by oeconomica. Economics, indeed, not as a science in itself as we know it today, but as an "art," was presented by Aristotle, and by the literature of the ancien régime, as the discipline that involves a "just" government of the house (see Continisio 1994). It was part of moral philosophy. The governance of the house was different from the governance of the city or kingdom (civitas) because their domains of action were different, and both were well circumscribed. But both required the same practical virtue and ability in order to achieve the just, virtuous, and mediocres order. Indeed, the father of the family, as the "prince" of his family, was required to be virtuous, to have "economic

7. Medietas and mediocritas are equivalent and will be used interchangeably. I will use the Latin term, since its translation into "mediocrity" would add a negative connotation that was absent in the ancient word.

8. See, for example, Bishop Berkeley's (1975) mathematics and theory of vision which, read as a scientific work or as metaphors, express the same distrust for infinity and extremes. See Levy 1992. 
prudence": "The practical character of economics . . , following the traditional Aristotelian canons, puts it among the 'operative' disciplines that, unlike the 'contemplative' disciplines, which address the knowledge of things that are necessary, natural, and independent from human will, address the 'contingent' things, which are subject to human will, in order to guide action toward the just end. The art of good governance of the house "is subjected to prudence, and it is domestic prudence itself"' (Frigo 1995, 36; my translation).

\section{The Influence of Medietas on Adam Smith}

With this in mind, read Smith's "advertisement" to the last edition of The Theory of Moral Sentiments that he edited after writing The Wealth of Nations:

In the last paragraph of the first Edition of the present work, I said, that I should in another discourse endeavour to give account of the general principles of law and government, and of the different revolutions which they had undergone in the different ages and periods of society; not only in what concerns justice, but in what concerns police, revenue, and arms, and whatever else is the object of law. In the Enquiry concerning the Nature and Causes of the Wealth of Nations, I have partly executed this promise; at least so far as concerns police, revenue, and arms.

Smith, therefore, regarded The Wealth of Nations as continuing the sequence of thoughts set out in The Theory of Moral Sentiments. It seems that for Smith, the starting point to understanding The Wealth of Nations is The Theory of Moral Sentiments. ${ }^{9}$

In The Theory of Moral Sentiments, Smith shows man in all his dimensions, as the classics did. Individuals are characterized by a plurality of different feelings, both toward themselves and toward others, ranging from selfishness to benevolence. It is explicitly in part 7 of The Theory of Moral Sentiments where, dealing with moral philosophy as a system, Smith criticizes some then-modern interpretations of ethics as presenting human behavior as motivated by only one thing, and he leaves little doubt about his borrowing from classical thought the idea of virtue as medietas between opposing extremes. And it is not by chance that Smith 
focuses on a variety of different passions, contrasting himself with some of his contemporaries, teachers, and friends. Indeed, if there were just one motivation for our behavior, where would virtue be? If there were just one extreme, where would the "just middle" of opposed passions be? To have a point in the middle, at least two extremes, and not just one, have to exist. Indeed, at the practical and individual level, a completed and developed human being, with the help of the impartial spectator, has to balance all his feelings, and by achieving such a balance, he will be virtuous. At the abstract and in a sense aggregate level, a completed and developed moral system has to include all feelings too, and virtue will consist in the proper, just, balanced combination of them.

Remember that from what Smith told us in the advertisement of his last edition of The Theory of Moral Sentiments, his project was a large one. With The Theory of Moral Sentiments, he built a moral structure for human beings. With The Wealth of Nations Smith analyzed how the same man full of different passions would set in a "police, revenue, and arms" context. The same individual passions can be amplified or restrained in different proportions by different sets of political and economic institutions. The "prudent man" described in The Theory of Moral Sentiments is essentially the same person assumed to be at work in the commercial society described in The Wealth of Nations. Indeed, if it is true that in The Wealth of Nations the predominant presence is self-love, it is also true that it is never the only one (Bittermann 1940a, 1940b).

Smith was conscious, though, that virtue is not easy to achieve, that people are imperfect, and not perfectible. At the same time, Smith was conscious that absolute principles may not always be appropriate, and that a contextual analysis may offer a more appropriate basis for judgment. So, for example, sympathy is good, but not always strong; selfinterest is good, but not on all occasions; and a limited presence of government is also good, but not necessarily all the time.

More specifically, self-interest tends to prevail over sympathy in the context of market transactions. First of all, we do not get our dinner "from the benevolence of the butcher"-instead, self-interest prevails. Moreover, sympathy, which usually can constrain self-interest, tends to decrease the less we know about another person. But when dealing with strangers, competition and repeated dealings offer "natural" restraints to an otherwise prevalent selfishness, and trade is able to channel in a positive manner one's self-interest (WN, I.ii.2). The market, here, is 
able to bound human passions, keeping them balanced, preventing them from falling into vicious extremes. The presence of self-interest is seen, in this context, in a positive light — and as maintaining social harmony. When, instead, we are faced with an institutional context in which selfinterest is left unbounded, self-interest assumes a negative connotation. Unbounded self-interest can become "rapacity," according to Smith. It is indeed self-interest that, breaking its bounds, flatters government in order to achieve monopolistic privileges, abandoning free trade. Engaging in unbounded selfish possibilities and acquiring an "artificially" predominant role through government-granted monopolies breaks the natural harmony of society by damaging the whole in favor of a small part (WN, I.xi). Virtue is medietas; if one extreme prevails and the just middle is abandoned, the consequences cannot be positive. The dominance of self-interest, sustained by the force of government, not only moves the individual away from virtue, but also society away from harmony.

Similarly, Smith is ready to accept both the goodness of the absence and of the presence of government in society, depending on the specific context. If sympathy is weak, if the impartial spectator makes a mistake, if man cannot perceive well, a free market is preferred. But when, for whatever reasons, the free market fails, government intervention can do good. ${ }^{10}$ An example of this positive role for government intervention is Smith's controversial position on public schools (controversial only if seen out of context). Smith noted that if specialization, as self-interest, is present in the "proper quantity" if it is balanced with other individuals' activities in the proper proportion (that depends on the specific institutional and historical context), its role is positive. Specialization can do wonders at the individual and societal level. But if disproportional with respect to the "proper level," the consequences are negative, both at the individual and at the societal level (WN, V.i.f.50). How to maintain specialization in the "proper measure"? Smith provided us an antidote. Education and religion are indeed the instruments that, if promoted among the workers, can keep alive their mind and rebalance their selves (WN, V.i.f). And if the market fails to provide schools, government is welcome to intervene, so that the just and good medietas can be maintained both at the individual level as well as at the social level.

10. On the active role of government in Smith, see Jacob Viner's 1927 essay "Adam Smith and Laissez-Faire" reprinted in Viner 1991. 
This being the case, Henry Bittermann (1940a, 516) is correct in saying, "Paradoxical as it may seem, the theory of ethics was less directly normative than the scientific work on economics. The moral theory was in the main descriptive; the economic theory neatly wove prescriptive elements into its descriptive-predictive fabric."

It follows, also, that David Levy (1987) is correct in saying that legal restraints in the economy (and not only there) work like a sort of moral code in Smith's framework. ${ }^{11}$

\section{The Influence of Systematic Error on Adam Smith}

How can sympathy be weak? the impartial spectator make a mistake? man not perceive well? and the market fail? All these problems can be related to systematic biases.

An example of weak sympathy is experienced the farther away (literally and figuratively) people are from each other. If this is the only problem, the market will usually take care of it. But more problems may come when accompanied by other defects.

As human beings have to learn how to perceive distances, human beings have to learn how to sympathize. Sympathy is the natural component of human beings that allows the existence of the impartial spectator. But the spectator who is in us since birth is "partial" (Levy 1995). This implies that the Smithian man is born with a strong egocentrism. By interacting with others, the individual realizes that he is not "the center of the universe," as he thought. Through his relationships with others, by imagining himself in somebody else's shoes, the individual grows morally and slowly transforms his internal spectator from partial to impartial.

The impartial spectator is therefore the fruit of a continuous interior work, helped by the presence of others, which leads the morality of the individual to maturity. The full maturity of the individual, his full morality, cannot be taken for granted. Virtue is a conquest, not a given.

11. "Smith's opinion that government officials have no role to play in the direction of private resources does not imply that law has no role. While Smith knew the notion of 'government failure' as well as modern public-choice theorists, legal restraints in Smith's work have an interesting similarity to moral codes. When people are not fully aware of the consequences of their action, both can provide benefits to the constrained individual. . . In this case, where law can improve social well-being, Smith favors it" (Levy 1987, 399-400). 
What about the possibility that human beings will make mistakes because of systematic bias? Smith opens both The Theory of Moral Sentiments and The Wealth of Nations by describing exactly this possibility.

The Theory of Moral Sentiments begins with descriptions of how we constantly make mistakes because we imagine ourselves in someone else's condition and keep reasoning with our own mind, not theirs. So we feel sorry for the dead because they are alone and cold under the ground, while they, being dead, cannot feel anything. We feel sorry for the mentally insane, "but the poor wretch, who is in it, laughs and sings perhaps, and is altogether insensible of his own misery" (TMS, I.i.11). And so on ...

The Wealth of Nations opens with the famous misperception:

[The division of labor] is commonly supposed to be carried furthest in some very trifling [manufacturing operations]. . . In those great manufactures, on the contrary, ... the work may really be divided into a much greater number of parts, than in those of a more trifling nature, [although] the division is not near so obvious, and has accordingly been much less observed. (WN, I.i.2)

Systematic errors in perception turn out to be the norm. The implication is therefore that the starting point, the assumption (which in Smith's case is empirical observation), from which Smith starts to work, is perception errors that lead to systematic errors. And in the presence of systematic errors social harmony may have some troubles. One of these troubles is indeed with respect to the interest rate.

Even chapter 4 of book 2, "On Stock Lent at Interest," opens with the description of a common error in perception. There are two kinds of borrowers, says Smith: the industrious borrower and the prodigal borrower. The industrious borrower will borrow capital to use it in a profitable way; he will be able to pay back the lender. The prodigal borrower will borrow for immediate consumption and "will soon be ruined, and he who lends to him will generally have occasion to repent of his folly" (WN, II.iv.2). Many think that the proportion of the two kinds of borrowers is either equal or skewed toward the prodigal, but this cannot be the case. To verify that this is a biased perception, ask a rich lender: he will laugh at the idea of lending to the prodigal: "From the regard that all men have for their own interest, we may be assured, that it cannot happen [to lend to both the industrious and the prodigal] so very frequently as we are sometimes apt to imagine. Ask any rich man of common prudence, to which 
of the two sort of people he has lent the greater part of his stock, to those who, he thinks, will employ it profitably, or to those who will spend it idly, and he will laugh at you for proposing the question" (WN, II.iv.2).

\section{Making Sense of Smith on Usury}

Now that we are equipped with Smith's analytical instruments-medietas and systematic perception error-we can try to understand why Smith favors usury laws.

Smith is saying that the interest rate should be regulated by law, and fixed "somewhat above the lowest market price" (WN, II.iv.14). The other two rates he considers are no rate at all ("prohibition of interest") and "usury." Note what we have: two extremes and a middle position. Prohibition is the lower extreme, usury is the upper extreme, and the legal rate is the middle point.

Smith as a moral philosopher teaches us that the extremes are dangerous and should be avoided. Smith as an economist says that both prohibition of interest and usury rates are deleterious and should be avoided.

Here is how Smith describes the consequences of prohibiting interest:

In some countries the interest of money has been prohibited by law. But as something can every-where be made by the use of money, something ought every-where to be paid for the use of it. This regulation, instead of preventing, has been found from experience to increase the evil of usury; the debtor being obliged to pay, not only for the use of money, but for the risk which his creditor runs by accepting a compensation for that use. He is obliged, if one may say so, to insure his creditor from the penalties of usury. ( $W N$, II.iv.13)

Indeed, "no law can reduce the common rate of interest below the lowest ordinary market rate at the time when that law is made. Notwithstanding the edict of 1766, by which the French king attempted to reduce the rate of interest from five to four per cent., money continued to be lent in France at five per cent., the law being evaded in several different ways" (WN, II.iv.16).

And here is how he describes the consequences of usury:

The legal rate, it is to be observed, though it ought to be somewhat above, ought not to be much above the lowest market rate. If the legal rate of interest in Great Britain, for example, was fixed so high as eight 
or ten per cent., the greater part of the money which was to be lent, would be lent to prodigals and projectors, who alone would be willing to give this high interest. Sober people, who will give for the use of money no more than a part of what they are likely to make by the use of it, would not venture into the competition. A great part of the capital of the country would thus be kept out of the hands which were most likely to make a profitable and advantageous use of it, and thrown into those which were most likely to waste and destroy it. (WN, II.iv.15)

What Smith is describing in this passage is adverse selection. Given the presence of heterogeneous borrowers-prodigals and projectors as well as sober people - the higher the interest rate, the riskier the projects (the ones by prodigals and projectors) that will be financed, leaving out more sober entrepreneurs.

Now, consider Smith's analysis on risk premium: lending money gives the lender a higher return than investing in land, which is more stable. "The superior security of land, together with some other advantages which almost every-where attend upon this species of property, will generally dispose him to content himself with a smaller revenue from land, than what he might have by lending out his money at interest" (WN, II.iv.17).

Indeed, high interest rates as well as rates of profits are present when there is high risk. And the riskier the project, the higher the risk premium will be. Smith has already exposed this fact in book 1 of The Wealth of Nations, in chapter 10, part 1, titled "Inequalities Arising from the Nature of the Employments Themselves." In paragraph 33, Smith states:

The ordinary rate of profit always rises more or less with the risk. It does not, however, seem to rise in proportion to it, or so as to compensate it completely. Bankruptcies are most frequent in the most hazardous trades. The most hazardous of all trades, that of a smuggler, though when the adventure succeeds it is likewise the most profitable, is the infallible road to bankruptcy. The presumptuous hope of success seems to act here as upon all other occasions, and to entice so many adventurers into those hazardous trades, that their competition reduces the profit below what is sufficient to compensate the risk. To compensate it completely, the common returns ought, over and above the ordinary profits of stock, not only to make up for all the occasional losses, but to afford a surplus profit to the adventurers of the same nature with the profit of insurers. But if the common returns 
were sufficient for all this, bankruptcies would not be more frequent in these than in other trades. (WN, I.x.b.33)

Smith is therefore saying that prohibition of interest causes usury, and usury rates are harmful to the individual and to the economy because of the problems described above. A middle position is therefore preferred to the extreme positions. But why would interest rates rise to extreme levels? Why should the "just middle" be legally enforced?

Smith leads us to the answer when talking about the problems caused by high rates. People are attracted by the high profit of a risky project, but the more projectors, the lower the profit will be. Many will get bankrupted. And so the question: If this is known, why do they not stay out of that activity? Why do they engage in such projects? Smith's answer: systematic bias. It is "the presumptuous hope of success [that] seems to act here as upon all other occasions" (WN, I.x.b.33; emphasis added) that causes miscalculation of the probability of success. The projector, like the gambler, is facing a lottery-like situation. He is biased; he thinks he is "the center of the universe"; he thinks others will fail, but not him. He will therefore overestimate the probability of his success and underestimate the probability of his failure.

The over-weening conceit which the greater part of men have of their own abilities, is an ancient evil remarked by the philosophers and moralists of all ages. Their absurd presumption in their own good fortune, has been less taken notice of. It is, however, if possible, still more universal. There is no man living who, when in tolerable health and spirits, has not some share of it. The chance of gain is by every man more or less over-valued, and the chance of loss is by most men under-valued, and by scarce any man, who is in tolerable health and spirits, valued more than it is worth. (WN, I.x.b.26; emphasis added)

Most of the times in which we face a decision under uncertainty, we are facing a maximization problem with "incorrect" data. The expected benefit, biased by the projector's/gambler's presumption, will exceed the expected cost of the project/bet. If the information used in his calculation were not biased, the expected cost would exceed the expected benefit and he would restrain himself from engaging in such a risky project. But the information is biased, so the project/bet will be undertaken.

Since people tend to systematically overestimate their probability of success, there is the tendency for interest rates to be higher than the 
market-clearing level. The overestimated interest rate leads to the problems of adverse selection, financing too many overly risky projects. A ceiling is therefore important to prevent the degenerative consequences of this process.

Confirmation of this reading of Smith comes from his adversary in the usury debate. Jeremy Bentham recognizes Smith's argument on systematic bias, and turns it against Smith: if there is a bias on the borrower's side, there is also another bias, which goes in the opposite direction, as far as the lender is concerned. Even if the projector has a tendency to overestimate his probability of success, it is likely that the lender will underestimate it. The problem caused by the projector's bias is solved by the (opposite) lender's bias. These two opposite biases cancel each other out, making usury laws unnecessary.

True it is, that in the jumble of occurrences, an over-sanguine projector may stumble upon a patron as over-sanguine as himself; and the wishes may bribe the judgment of the one, as they did of the other. The opposite case, however, you will allow, I think to be by much the more natural. Whatever a man's wishes may be for the success of an enterprize not yet his own, his fears are likely to be still stronger. That same pretty generally implanted principle of vanity and self-conceit, which disposes most of us to over-value each of us his own conceptions, disposes us, in a proportional degree, to under-value those of other men. (Bentham [1787] 1952, 181)

To further corroborate this reading of Smith, Bentham is explicit in the need to relate the usury problem to the lottery problem, where Smith openly presents his theory of systematic bias. And while Bentham also recognizes the "lottery problem" in projects, he disagrees with Smith on the consequences. Bentham, differently from Smith, sees the "inventionlottery" not as what today we would call a negative externality, but as, in today's words, a positive externality.

Consider, Sir, that it is not with the invention-lottery (that great branch of the project-lottery, for the sake of which I am defending the whole, and must continue so to do until you or somebody else can shew me how to defend it on better terms). It is not I say with the invention-lottery, as with the mine lottery, the privateering-lottery, and so many other lotteries, which you speak of, and in no instance, I think, very much to their advantage. In these lines, success does not, 
as in this, arise out of embers of ill success, and thence propagate itself, by a happy contagion, perhaps to all eternity. (Bentham [1787] 1952, 182)

The problem of negative externality related to lotteries is picked up by David Levy $(1987,388)$, who, commenting on Smith's problem with gambling due to misperception, says, "So what? People, in the eyes of moralists of all parties, have always appeared foolish. If people are willing to pay for the pleasure of gambling or they fail to compute the correct odds of the gamble, aren't they bearing the consequences themselves? In Smith's account, this they are not. When investors gamble, they bet society's resources."

Actually, by betting society's resources, as also Joseph Jadlow (1977) shows, they are also preventing others from making productive and safer investments. But while Jadlow and Levy claim different risk preferences, Smith claims that since we are not calculating with "true" values, we can, without realizing it, create externalities, because we may be maximizing our utility and at the same time turning our bill to someone else.

It is important to notice that Smith is aware of the difficulties of picking the "correct" legal ceiling. It is a difficult task for everybody, including government officials ( $W N$, II.iv.14).

Smith seems willing to impose an interest rate by law, incurring the risk that the interest imposed is not the correct one, because individual virtue and social virtue are interdependent. When individuals are virtuous, society, as a reflection, is virtuous as well. When society is governed by mediocres virtuous rules, individuals have more incentive to be virtuous. In other words, since laws are general rules, laws are required, because the way to overcome systematic biases, at the individual as well as at the social level, is to rely on general (moral) rules.

To see the importance of general moral rules in dealing with systematic biases we have to rely, again, on the base of The Wealth of Nations, which is to say, on The Theory of Moral Sentiments.

This is what Smith has to say about "the nature of self-deceit, and of the origin and use of general rules" (TMS, III.4):

There are two different occasions upon which we examine our own conduct, and endeavour to view it in the light in which the impartial spectator would view it: first, when we are about to act; and secondly, after we have acted. Our views are apt to be very partial in both cases; 
but they are apt to be most partial when it is of most importance that they should be otherwise. (TMS, III.4.2)

Smith therefore claims that we judge our actions in a biased fashion, both before and after the action, since "every thing appears magnified and misrepresented by self-love" (TMS, III.4.3). Indeed, "it is so disagreeable to think ill of ourselves, that we often purposely turn away our view from those circumstances which might render that judgment unfavourable" (TMS, III.4.4).

These biases have disastrous consequences, especially because they undermine social harmony. The way to maintain the "proper and just order," which is to say the way to maintain the virtuous order of society, is to follow "general rules." These general rules are moral and help the moral development of the individual as well as the orderly life of society.

This self-deceit, this fatal weakness of mankind, is the source of half the disorders of human life. ...

Nature, however, has not left this weakness, which is of so much importance, altogether without a remedy; nor has she abandoned us entirely to the delusions of self-love. Our continual observations upon the conduct of others, insensibly lead us to form to ourselves certain general rules concerning what is fit and proper either to be done or to be avoided. ...

It is thus that the general rules of morality are formed. . . .

Those general rules of conduct, when they have been fixed in our mind by habitual reflection, are of great use in correcting the misrepresentations of self-love concerning what is fit and proper to be done in our particular situation. (TMS, III.4.6-8, 12)

As mentioned above, in the ancien régime, the individual and society are strictly interrelated. The virtues or the vices of the individual are reflected in, and are a reflection of, the virtues and vices of his society. ${ }^{12}$ The rules for individual virtue are the rules for a good social order. And "in medio stat virtus" ("virtue is in the middle," which is to say, medietas) is one of the most general rules to reach virtue and social harmony.

12. Bernard Mandeville distances himself in a revolutionary fashion from this position, by contrasting individual and social vices and virtues. Not by chance, Smith attacks and criticizes Mandeville openly and at length in TMS, VII.ii.4. 
Smith's favor for usury laws and the free market are consistent with each other when we consider "stay in the just middle" as the most general rule to follow in order to achieve individual virtue as well as social harmony. Markets are, most of the time, able to achieve medietas without any external help. Interest rates instead are not able to achieve such results. Individuals are unfortunately but inevitably characterized by systematic perception biases. They systematically tend to overestimate the probability of winning in the "project-lottery." By leaving the situation unregulated, extremely high usury rates would arise. The traditional solution to this usury problem was extreme also: abolish the interest rate in toto. Therefore we would fall in one of either two opposite extremes, both dangerous. One extreme would be usury, the deleterious effect of which would lead to adverse selection, as shown above. The second extreme would be the abolition of the interest rate, which brings consequences as deleterious as its opposite extreme.

Moral philosophy teaches us that the dangers of extremes can be overcome by following a general virtuous rule, which would lead to the "just and proper order": avoid the extremes, stay in the middle. In the case of the interest rate, the middle position would be a moderately positive rate of interest. Indeed, Smith proposes a legal maximum interest rate slightly above the market rate, which is more than zero and less than the usury levels. The rate should be "legal" because our systematic mistakes of perception would lead us to slide toward the upper extreme.

\section{Reaching Smith's Position on Usury from Modern Mainstream Analysis}

Part of modern economics is unable to reconcile Smith's justifications for usury laws with other positions held by Smith. This inability stems from the fact that modern economists insist on using their own instruments, rather than Smith's. When modern economists attempt to see the consistency in Smith by analyzing his conclusions, they end up using faulty reasoning; when they attempt to see the consistency by focusing on his analysis, they fail to reach the same conclusion as Smith.

I view at least three major ways of analyzing the consistency of Smith on usury laws in today's literature. One path of analysis, even if not necessarily following Smith's analysis, agrees with or justifies Smith's support for usury laws (what I call the "Keynes-like" interpretation). Another modern line of thought follows Smith's analysis closely but reaches 
opposite policy conclusions (what I call the "Stiglitz and Weiss-like" interpretation). In order to maintain my argument within tractable limits, I will present only a couple of scholars who can be located in each interpretative framework. The third line of analysis feeds on das Adam Smith Problem and cannot make any sense of Smith's position on usury, accusing Smith of radical inconsistency or of superficial analysis (see for example Robbins 1968 and Stigler 1975). Given my interpretation of Smith, das Adam Smith Problem does not arise. I will therefore dismiss this failed attempt to understand Smith and, to avoid redundancy, I will not comment on it.

\section{The Keynes-Like Interpretation}

In what I call the Keynes-like interpretation I bundle together scholars who are not necessarily Keynesian, but who interpret Smith's support of usury laws in terms of growth, similarly to Keynes. I consider three examples of analysis within this framework. In the first example, Smith's support for usury laws is seen as a way to encourage investment in lowrisk sectors of the economy, stimulating growth. The second example answers Bentham's criticism, that usury laws impede the financing of entrepreneurial activities, retarding innovation and growth. In the third example, usury laws are viewed as a weapon against rent-seeking, which otherwise would bring a country to stagnation. For each of these examples, the modern argument is presented first, followed by some of the reasons why that argument fails to find consistency in Smith's thought.

I name this line of interpretation "Keynes-like" since Keynes aligns himself on Smith's side of the barricade, supporting usury laws.

Keynes ([1936] 1997, 351) wrote, "The rate of interest is not selfadjusting at a level best suited to the social advantage but constantly tends to rise too high, so that a wise Government is concerned to curb it by statute and custom and even by invoking the sanction of the moral law." Keynes favors usury laws because he thinks that they will stimulate economic growth by increasing investment. Income would increase as a consequence of the increased investment. But it has been noticed that Keynes does not offer any further specification (Blitz and Long 1965).

A first example of reasoning in the Keynes-like framework is by Levy (1987). Levy believes Smith favors usury laws because usury laws will discourage investment in risky sectors of the economy, like international trade, and will encourage investment in the safer sectors instead, such as 
agriculture. According to Levy, for Smith usury laws promote economic growth and therefore should be supported. ${ }^{13}$ But Levy's reading raises at least three problems, the most serious of which is that Smith's support for free trade becomes an unexplainable counterexample.

First of all, although Levy interprets Smith as saying that agriculture is the key to growth and that agriculture should be preferred to foreign trade, he also sees Smith as putting strong limitations on this statement. Levy noted that Smith also said agriculture is only the first stage of economic development. Indeed, developed countries increasingly depend on industry, specialization, and trade. But, if usury laws are useful because they support agriculture, and if agriculture is only the first stage of economic development, the implication would be that usury laws should be enforced only during the early stages of the economic development of a country. When a country reaches more advanced stages of economic development, the laws should be abolished. But this is not what Smith said. Second, in order to accept Levy's argument, it has to be proven that savings generated in the safe agricultural sector will move to the riskier foreign trade. If instead in rural society savings tend to be reinvested in agriculture (Blitz and Long 1965), usury laws would be useless, because they would prevent a transfer of resources (from agriculture to foreign trade) that would never take place anyway. Finally, arguing that for Smith economic growth heavily depends on domestic agriculture would leave unexplained why Smith champions free trade. So, for instance, following Levy's reasoning, Smith's vigorous support of anti-corn laws, which favor international trade over domestic agriculture, would be left unexplained. A modern reading of Smith's support of usury laws, such as Levy's, therefore, does not solve the puzzle of how Smith could support usury laws and the free market at the same time.

A second example of reading Smith on usury laws in the Keynes-like framework is Samuel Hollander (1999). Hollander explains why Bentham's criticisms of Smith's position on usury laws may be inappropriate, but he does not offer a solid explanation of why Smith favors such laws, nor of why Smith proposes the specific maximum legal rate for England that he does.

13. "Usury laws, in Smith's opinion, can benefit society by reducing the riskiness of society's investments. . . . By investing more in agriculture than in foreign trade, there is a net product which benefits society, but not necessarily the individual making the decision" (Levy 1987, 397). And: "The second determinant of growth is the composition of this productive labor: countries which employ more agricultural labor will grow most rapidly” (Levy 1987, 393). 
Hollander's analysis of the debate (or the lack thereof) between Bentham and Smith is a defense of Smith against Bentham. Bentham worried that Smith, proposing usury laws, would strangle innovation, investment, and growth. But, explains Hollander, within-family lending and equity financing were the most common way of bankrolling "innovations" during Smith's time; therefore, in practice, usury laws would not deter investment, development, and growth, showing that Bentham's criticisms of Smith are inaccurate. ${ }^{14}$ But were this the case, we would be left without an explanation for why Smith proposes laws against usury, since usury laws would block an interest rate for a loan that, in practice, is not requested. Moreover, Hollander himself recognizes that his reading of Smith faces another problem. If Smith's favor for usury laws is justified on practical grounds, the legal rate Smith picked as an example for England is inexplicable. Smith uses an interest rate that was below the market rate, rather than "slightly above," much before the last edition of The Wealth of Nations. Hollander cannot justify why Smith, having the time and the opportunity, did not revise the rate upward. On the other hand, when Smith's enterprise is analyzed in terms of a (moral) theoretical framework, rather than on a practical base, the attention is concentrated on the general principle-follow a general rule, legal when necessary, that keeps things in the "just middle," so that individual virtue and social harmony are achieved and preserved. The exact "practical" rate becomes, therefore, irrelevant.

Finally, let us analyze a third example of the Keynes-like interpretation of Smith's reasoning for supporting usury laws. In this reading, rent-seeking is considered the key for interpreting Smith on usury laws. ${ }^{15}$ Usury rates are viewed as the result of rent-seeking activities of the rich. But reading Smith as proposing usury laws against the deleterious rentseeking self-interest "of the rich" raises at least three new problems. First, Smith seems to have forgotten the distinction he previously made between lenders (savers) and merchants; second, he would have made, simultaneously, opposite assumptions on the saving propensity of human beings; and finally, he would have proposed policies difficult to sustain, given his premises.

14. "Smith might, therefore, have defended himself against Bentham's charges by insisting that, in practice, his support of the usury laws did not imply that investment-innovatory or otherwise-would be starved of funding" (Hollander 1999, 537).

15. I am indebted to an anonymous referee for considering this point of view. 
According to this view, Smith, like Keynes after him, believes that interest rates were kept artificially high by restrictions in the financial capital market and/or in its access. High interest rates are usually found in the absence of abundant capital and, vice versa, low interest rates are present where there is abundant capital (WN, I.ix.20 and II.iv.8, among the references). But market forces are not always free to work. Human intervention, via the power of legislation, can interfere and change the market results: "A defect in the law may sometimes raise the rate of interest considerably above what the condition of the country, as to wealth or poverty would require" (WN, I.ix.16).

The law is "defective," it is argued, because it is molded by the selfish demands of the rich. The rich, owning capital, want to maximize their returns, and they achieve this goal by asking for government protection so that they can restrict the quantity of capital in the market and seek higher rents. China is mentioned as a country in which there are "laws and institutions ... [that] establish the monopoly of the rich" and where, as a consequence, the interest rate is "large" (WN, I.ix.15).

Furthermore, Smith aggressively attacks attempts to form cartels or monopolies, attempts that are motivated by the voracity for profits of "merchants," "master manufacturers," and "dealers":

The interest of this third order [of those who live by profit], therefore, has not the same connection with the general interest of the society as that of the other two [of those who live by wages from labor and of those who live off of rent from land]. Merchants and master manufacturers are, in this order, the two classes of people who commonly employ the largest capitals.... [They know their interest very well.] The interest of the dealers ... in any particular branch of trade or manufactures, is always in some respects different from, and even opposite to, that of the publick. (WN, I.xi.p.10)

In this interpretative framework, Smith is claimed to propose usury laws to limit social abuses caused by these attempts at monopoly/cartel by those who live by profit.

The pillar of this line of argument is that lenders form a socially deleterious rent-seeking interest group. But this interpretation cannot account for previous claims of Smith regarding the identity of the lenders and their role in society. Indeed, arguing that the achievement of the lenders' interest is in conflict with the social interest implies, as shown above, that lenders, owning capital, are among those people who live by 
profit, the target of Smith's attacks. But the group of people that Smith attacks is composed only of merchants, master manufacturers, and dealers, as Smith specifies. Lenders are not part of this potentially dangerous group. Lenders are indeed part of a different category of people-the "monied interest"- which differs from the "trading and manufacturing interest," since merchants, master manufacturers, and dealers do not lend their capital, but rather, they employ their own capital. "As such capitals are commonly lent out and paid back in money, they constitute what is called the monied interest. It is distinct, not only from the landed, but from the trading and manufacturing interests, as in these last the owners themselves employ their own capitals" (WN, II.iv.5; emphasis added).

Indeed, according to Smith, lenders are savers (WN, II.iii.4, 13), and savers of capital are a different group of people from the one that employs or consumes capital. 16 And Smith lauds the "frugal man" who saves (WN, II.iii.19). ${ }^{17}$ Lenders, being savers, are not an interest group that harms society. On the contrary, lenders benefit society.

A second set of difficulties occurs following this Keynes-like interpretation of Smith's usury laws. Reading lenders as able to control access to capital in the market, as proposed above, forming what today we call a cartel, fails to consider how lenders would hold their cartel in place over time. The rent-seeking cartel of lenders could stick together either through no capital growth or through preventing the increasing capital from affecting interest rates. But both of these solutions are implausible. In Smith's framework, indeed, the driving force of capital accumulation is saving. ${ }^{18}$ The absence of capital growth, therefore, can be achieved by assuming that everybody is prodigal, that is, by assuming that there is no parsimony. If nobody saves, capital cannot grow. But Smith denies this option. ${ }^{19}$ Alternatively, consider what happens when the assumption of

16. "What is annually saved is as regularly consumed as what is annually spent, and nearly in the same time too; but it is consumed by a different set of people" (WN, II.iii.18; emphasis added).

17. Smith reproves instead the prodigal man who "tends not only to beggar himself, but to impoverish his country" (WN, II.iii.20).

18. "Parsimony, and not industry, is the immediate cause of the increase of capital. Industry, indeed, provides the subject which parsimony accumulates. But whatever industry might acquire, if parsimony did not save and store up, the capital would never be the greater" ( $W N$, II.iii.16).

19. "But the principle which prompts to save, is the desire of bettering our condition, a desire which, though generally calm and dispassionate, comes with us from the womb, and never leaves us till we go into the grave" (WN, II.iii.28). 
a zero savings rate does not hold. Lenders, driven by their self-interest, lend to make money. Lenders therefore invest in profitable enterprises (WN, II.iv.2). The profitable businesses will generate new capital. Part of the new capital will be reinvested in the same activity and part will be saved and lent/invested in a different, new profitable activity ( $W N$, II.iii.4, II.iii.15). With parsimony, therefore, the total quantity of capital increases. By increasing the quantity of capital, interest rates will spontaneously decrease (e.g., $W N$, II.iv.8). If there is downward pressure on interest rates due to the financing of successful enterprises and a positive savings rate, and if the lenders are a cartel, the cartel is subject to competitive pressures that may lead to its disintegration. But if lenders are self-interested rent-seekers, as assumed above, they can ask for and achieve protective laws. The logical prediction derived from this reasoning would be that the lenders ask for a price-floor to prevent the interest rate from decreasing. This, though, is unheard of.

Furthermore, granting some credit to the possibility of adverse selection as presented by Smith ( $W N$, II.iv.15), we face the problem of a group of lenders artificially holding up interest rates, but only to finance risky projects with a low probability of being repaid. This seems to contradict the idea that the "third order" (those who live by profit) knows its interest (WN, I.xi.p.10).

Finally, the conclusion of this variant of the Keynes-like interpretation is that the source of the problem is "bad laws," as in China. The government, which gave in to the flattery "of the rich," is the source of the "bad laws" that generated usury rates. Were the "rent-seeking interpretation" of usury laws correct, the government would be left with no apparent good reason for accepting the implementation of usury laws, because the powerful rich would seek to maintain their protection rather than accept its dismantling. Moreover, assuming it were true that usury rates are caused by rent-seeking laws and ignoring the above objection, Smith would have avoided many predictable problems by proposing to abolish those laws, rather than adventuring into such muddy territory (as recognized by Smith himself in $W N$, II.iv.14) as fixing interest rate ceilings. Were this "rent-seeking argument" correct, Smith would leave us with new problems regarding his consistency, since the government would simultaneously and inexplicably be the source of the problem as well as its solution.

A reading with modern instruments is, once again, more problematic than a reading with old instruments. 


\section{The Stiglitz and Weiss-Like Interpretation}

The other modern approach to Smith on usury is to try to follow Smith step by step in his analysis of the interest rate ceiling and restate it in more rigorous analytical terms. I call this approach the "Stiglitz and Weiss-like" interpretation because Joseph Stiglitz and Andrew Weiss (1981) were able to model credit rationing in markets with imperfect information in a way that is strikingly similar to Smith's analysis, as also Hollander (1999) recognizes. Stiglitz and Weiss, as well as Smith, show the existence of non-market-clearing equilibrium interest rates because of moral hazard and adverse selection. Moreover, four years before the publication of the renowned article by Stiglitz and Weiss, Joseph Jadlow (1977) successfully modeled as an externalities problem the analysis that leads Smith to support usury laws.

The problem with this modern line of modeling Smith is that, independent of which model is used, the policy conclusions (of both StiglitzWeiss and Jadlow) are diametrically opposed to Smith's. While Smith concludes that there is a positive role for usury laws, the modern analyses lead us to consider usury laws as unnecessary.

Let us go back to Stiglitz and Weiss's analysis, at the base of which there is a market with imperfect information. Not surprisingly, Stiglitz and Weiss consider the problem of imperfect information in a principalagent framework, where the problem of gathering all the information is a monitoring cost. ${ }^{20}$ Stiglitz and Weiss, as modern economists, use modern tools, that is, they assume strict rationality that leads to "perfect" maximization. Stiglitz and Weiss proposed usury laws in the specific case in which the interest rate would be too low to finance a safe project, so that banks would pick a higher interest rate that would instead encourage riskier projects. But in normal conditions there is no need for usury laws, because the profit-maximizing bank would never ask usury rates. If Stiglitz and Weiss are correct, their analysis presents two opportunities to reconcile Smith's dilemma. If, in practice, the market interest rate would always be "too low," the bank would be led to pick the too high "risky" rate, therefore making usury laws optimal. Or,

20. The nature of the problem is important. Monitoring costs are costs related to vision, the fact that we simply cannot see with our own eyes everything relevant that is occurring. In Smith's framework, the ability to see (literally and figuratively) is generally biased, leading to systematic errors. See also Berkeley's "New Theory of Vision” in Berkeley 1975. 
what is perceived as the maximizing interest rate in reality is not, opening again the door to usury laws.

George Stigler (1988) understood that Smith's answer was the second one; he saw one of the different analytical tools that Smith used, but did not accept it. Smith built his system starting from observing human behavior and human errors. Stigler started from the assumption that systematic error was impossible. Stigler accused Smith of considering lenders as "foolishly shortsighted." Smith started from the observation that systematic error existed. For Smith, lenders are in fact shortsighted. But being shortsighted does not mean being "foolishly" so. Adam Smith, as a classical moral philosopher, uses ancient tools, that is, he observes "irrational" misperceptions that lead to gross mistakes.

The difference in the possibility of systematic perception error is important. It is this difference that makes many modern economists unable to rationally explain gambling or voting. Not surprisingly, Smith has no problem explaining these "irrational" behaviors (voting, actually, was not explained because it was not an issue in his time). As mentioned above, Smith believes that people have systematic misperceptions. Therefore, Smith is not saying that individuals, in our case gamblers as well as borrowers and lenders, are "irrational," but that they are maximizing with "incorrect" data. If Smith's individual would have had perfect perception, I believe he would have acted exactly like Stiglitz and Weiss's individual, Smith would have reached precisely the same policy conclusions as Stiglitz and Weiss, and Stigler would have been happier with Smith.

In Stiglitz and Weiss's world, human beings perceive perfectly, so a ceiling will generally be self-imposed by the banks themselves. In Smith's world, human beings have biased perceptions, so the ceiling will not appear spontaneously, but should be legally imposed in order to preserve social harmony.

\section{A Possible Response by Smith to Modern Economists}

The first modern economist who accused Smith of inconsistency because he favored the free market as he simultaneously favored usury laws was Jeremy Bentham ([1787] 1952). Bentham, in my reading, recognized one of the two instruments of analysis that Smith used-perception biases, and the systematic errors that follow—but failed to recognize and 
understand the other-moral philosophy; therefore, his attack against Smith's position.

Siding with Bentham, at least as far as his modern positive (amoral) tools of analysis are concerned, modern literature tries, in vain, to rationalize the relationship (or lack thereof) between Smith and Bentham. Jacob Viner (1965, 18-19) can be considered as a representative example:

A friend of Bentham's, George Wilson, reported to Bentham in a letter of Dec. 4, 1789, that Smith had in conversation with William Adam, another friend of Bentham, spoken respectfully of Bentham and of his argument in The Defense of Usury, and that Smith "seemed to admit that you were right." With only this to go on, Rae states that "Bentham won-what is rarer-his [i.e., Smith's] conversion from the doctrines impugned." Professor W. Stark has recently published the draft of a letter of Bentham to Smith written either late in 1789 or early in 1790, in which Bentham reports that he has heard of an apparent acceptance by Smith of Bentham's position, and asks for permission to make public Smith's conversion to Bentham's position. Smith died on July 17, 1790. Bentham received no reply to his letter, but there reached him at the same time as news of Smith's death "a present" from Smith in the form, according to Stark, of a presentation copy of The Wealth of Nations. [At this point is a footnote: See W. Stark, Jeremy Bentham's Economic Writings, London, 1952, I, 26-27, 189190. It seems more likely that it was either a copy of The Theory of Moral Sentiments only, or copies of both The Theory of Moral Sentiments and The Wealth of Nations, which Smith sent to Bentham in 1790. A fifth edition of The Wealth of Nations was published in 1789. A sixth edition of The Theory of Moral Sentiments was published in 1790, shortly before Smith's death. Bonar reports that University College, London, has Bentham's presentation copy of the sixth edition of The Theory of Moral Sentiments. (A Catalogue of the Library of Adam Smith, 2d ed., London, 1932, Introduction, p. xxxiii, and pp. 201-203). John Bowring, Bentham's editor, states that Bentham "received a copy of Smith's works which had been sent to him as a token of esteem." (The Works of Jeremy Bentham, John Bowring ed., Edinburgh, 1838 ff., III, 52, italics mine.)] From the information available all that can be safely inferred is that Smith bore Bentham 
no ill-will for his criticism and possibly did not deny that it had some force.

Smith's 1790 silence is seen as a possible implicit acceptance of Bentham's position, notwithstanding that even in the 1789 edition of The Wealth of Nations, Smith does not change his favorable attitude toward usury laws. Now, consider that, on his deathbed, Smith asked that all his unpublished manuscripts be burned, fearing that imprecisions would lead to misunderstanding of his thoughts (West 1976). But some modern readers claim that Smith believed that he had erred with respect to usury laws and that he left that error in place, although he had three years to correct himself. According to modern analysis, Smith not only was inconsistent in his thought, but reinforced his inconsistency by also acting inconsistently.

If we instead consider The Theory of Moral Sentiments as the key to understanding Smith's consistency, Smith answered Bentham (standing in for all the future economists who analyze Smith with modern tools) by sending him the last edition of his two volumes: The Wealth of Nations is unchanged on the usury laws regardless of many criticisms; read The Theory of Moral Sentiments to understand why.

\section{Conclusion}

Viewing Adam Smith as inconsistent because he promoted the free market and usury laws at the same time can be the result of analyzing his work with inappropriate instruments. Adam Smith's view of usury laws may represent the verbalization and the systematization of centuries of experience and observation that some modern economists tend to forget. Indeed, inappropriate instruments of analysis leave behind an author's contextual knowledge and therefore the possibility of fully understanding his work. When, instead, Smith's contextual knowledge is taken into account, different interpretative instruments emerge. I propose to see Smith's political economy as Smith saw it, namely as a branch of moral philosophy. If this is the case, two interpretative instrumentsvirtue in the form of medietas and systematic perception errors-expose the original logic of Smith's work and its consistency: the free market and legally controlled interest rates are both ways to follow the general moral rule, "in medio stat virtus," and to maintain an orderly good society. 


\section{References}

Aristotle. 1983. Physics: Books III and IV. New York: Oxford University Press.

Bentham, Jeremy. [1787] 1952. Defence of Usury. In Jeremy Bentham's Economic Writings, edited by W. Stark. George Allen and Unwin.

Berkeley, George. 1975. Philosophical Works, Including the Works on Vision. London: Dent.

Bittermann, Henry J. 1940a. Adam Smith's Empiricism and the Law of Nature: I. Journal of Political Economy 48.4:487-520.

1940b. Adam Smith's Empiricism and the Law of Nature: II. Journal of Political Economy 48.5:703-34.

Blaug, Mark. 2001. No History of Ideas, Please, We're Economists. Journal of Economic Perspectives 15.1:145-64.

Blitz, Rudolph, and Millard Long. 1965. The Economics of Usury Regulation. Journal of Political Economy 73.6:608-19.

Continisio, Chiara. 1994. La politia aristotelica: Un modello per la convivenza ordinata nella trattatistica politica italiana dell'Antico Regime. Cheiron, Saperi politici e forma del vivere nell'Europa d'Antico Regime 22:149-65.

Evensky, Jerry. 1998. Adam Smith's Moral Philosophy: The Role of Religion and Its Relationship to Philosophy and Ethics in the Evolution of Society. HOPE 30.1:17-42.

— 2001. Adam Smith's Lost Legacy. Southern Economic Journal 67:497-517.

Frigo, Daniela. 1995. Amministrazione domestica e prudenza "oeconomica": Alcune riflessioni sul saper politico di Antico Regime. Annali di storia moderna e contemporanea 1:29-49.

Griswold, Charles. 1999. Adam Smith and the Virtues of Enlightenment. Cambridge: Cambridge University Press.

Hollander, Samuel. 1999. Jeremy Bentham and Adam Smith on the Usury Laws: A "Smithian" Reply to Bentham and a New Problem. European Journal of the History of Economic Thought 6.4:523-51.

Jadlow, Joseph. 1977. Adam Smith on Usury Laws. Journal of Finance 32.4:11951200.

Kahneman, Daniel, Paul Slovic, and Amos Tversky. 1982. Judgment under Uncertainty: Heuristics and Biases. Cambridge: Cambridge University Press.

Kahneman, Daniel, and Amos Tversky. 1979. Prospect Theory: An Analysis of Decision under Risk. Econometrica 47 (March): 263-91.

Keynes, John Maynard. [1936] 1997. The General Theory of Employment, Interest, and Money. New York: Prometheus Books.

Levy, David M. 1987. Adam Smith's Case for Usury Laws. HOPE 19.3:387-400.

. 1992. Bishop Berkeley Exorcises the Infinite: Fuzzy Consequences of Strict Finitism. Hume Studies 18:511-36.

- 1995. The Partial Spectator in the Wealth of Nations: A Robust Utilitarianism. European Journal of the History of Economic Thought 2.2:299-326. 
Nelson, Benjamin. 1969. The Idea of Usury, from Tribal Brotherhood to Universal Otherhood. Chicago: University of Chicago Press.

Paganelli, Maria Pia. 2000. Adam Smith: Il primo o 1'ultimo? Annali di storia moderna e contemporanea $6: 421-34$.

Peters-Fransen, Ingrid. 2000. The Canon in the History of the Adam Smith Problem. In Reflections on the Classical Canon in Economics, edited by Evelyn L. Forget and Sandra Peart. London: Routledge.

Plato. 1972. Philebus. Cambridge: Cambridge University Press.

Robbins, Lionel. 1968. The Theory of Economic Development in the History of Economic Thought. London: Macmillan.

Smith, Adam. [1776] 1981. An Inquiry into the Nature and Causes of the Wealth of Nations. Indianapolis: Liberty Fund.

— [1759] 1984. The Theory of Moral Sentiments. Indianapolis: Liberty Fund.

Stigler, George J. 1975. The Citizen and the State: Essays on Regulation. Chicago: University of Chicago Press.

- 1988. Memoirs of an Unregulated Economist. New York: Basic Books.

Stiglitz, Joseph E., and Andrew Weiss. 1981. Credit Rationing in Markets with Imperfect Information. American Economic Review 71.3: 393-410.

Tribe, Keith. 1999. Adam Smith: Critical Theorist? Journal of Economic Literature 37.2:609-32.

Viner, Jacob. 1965. Guide to John Rae's Life of Adam Smith. New York: Kelley.

. 1991. Essays on the Intellectual History of Economics. Princeton, N.J.: Princeton University Press.

West, Edwin. 1976. Adam Smith: The Man and His Works. Indianapolis: Liberty Press.

Young, Jeffrey T. 1997. Economics as a Moral Science: The Political Economy of Adam Smith. Lyme, N.H.: Edward Elgar. 